\title{
Postmortem Interval Estimation Time from Algormortis Temperature of Rats Expressed by MARS Model Approach
}

\author{
Dwi M. Syabani ${ }^{1}$, Hana Eliyani², Suharsono², Fedik A. Rantam³, \\ and Anwar Ma'ruf4 \\ ${ }^{1}$ Undergraduate student \\ ${ }^{2}$ Departement of Veterinary Anatomy \\ ${ }^{3}$ Departement of Veterinary Microbiology \\ ${ }^{4}$ Departement of Basic Veterinary Science \\ Faculty of Veterinary Medicine, Universitas Airlangga \\ Kampus C Mulyorejo Surabaya 60115 Indonesia
}

\section{Abstract}

Estimation of Postmortem is one of the challenges in forensic science. The aim of this study was to construct a MARS model of Postmortem interval estimation time (PMT)

Corresponding Author:

Hana Eliyani

eliyanihana@yahoo.com

Received: 03 October 2017

Accepted: 10 October 2017

Published: 29 November 2017

Publishing services provided

by Knowledge E

(a) Dwi M. Syabani et al. This article is distributed under the

terms of the Creative

Commons Attribution License,

which permits unrestricted

use and redistribution

provided that the original

author and source are

credited

Selection and Peer-review under the responsibility of the VMIC Conference Committee. from algor mortis temperature in Rat. Sixteen healthy male rats (Rattus norvegicus), onemonth old and weigh 100 gram were randomly divided into two groups (eight/each group) and were acclimated respectively among the ambient room (temperature over $28^{\circ} \mathrm{C}$ ) and at the conditioning room (temperature over $20^{\circ} \mathrm{C}$ ). The animals then were sacrificed in two days (four rats/day for each divided room) then algor mortis by rectal temperature were recorded after death at 0 and 2,4,6,8, 10,12, 14,16, 18,20 till $22 \mathrm{~h}$ respectively. The MARS model is nonlinear regression but performed as a multilinier curve that can have splines fitting and be defined as function model $Y=$ $35.321+1.253$ * $\mathrm{BF}_{1}+0.436$ * $\mathrm{BF} 2-1.319$ * $\mathrm{BF} 3$; and on $20^{\circ} \mathrm{C}$ condition room as $\mathrm{Y}=$ $29.980+1.354$ * $\mathrm{BF}_{1}+0.799 * \mathrm{BF}_{2}-1.347$ * $\mathrm{BF} 3$. Therefore, performance model was comprised by multilinier curve, then function model of algor mortis on ambient room be defined into three PMT intervals i.e: 1$\left.) Y=37,94-0.11^{\star}(0-2 h)(p>0.00) ; 2\right) Y=40.88-$ $1.87^{*}(2-6 h)(p<0.00)$ and 3$) Y=30.82-0.09^{*}(6-22 h)(p<0.00)$ while on $20^{\circ} \mathrm{C}$ condition room, was: 1) $\left.Y=34.78-0.09^{*}(0-2 h)(p<0.00) ; 2\right) Y=37.97-2.38^{*}(2-6 h)(p<0.00)$ and 3$) Y=25.36-0.04^{*} 6-22 \mathrm{~h}(\mathrm{p}>0.00)$. The acceleration of the declining algor mortis at conditioning room showed steeper than on ambient room at 2-6h PMT interval ( $B$ : 2,38 vs 1,87). Postmortem Time Interval Estimation from Algormortis Temperature of Rats could be expressed by MARS Model. The pattern model of estimation comprised by multilinear curve with splines was fitted at both of the experimental rooms.

Keywords: Postmortem time interval, algor mortis, MARS model estimation. 


\section{Introduction}

Some forensic Researches have been attempted in order to evaluate time since death (TSD). The correlation of postmortem time (PMT) interval with body cooling after death (algor mortis) have been established and confirmed in forensic studies. In most cases, soon after death occurs, the body temperature began to drop and continued until the internal temperature reaches the temperature of the environment. Rodrigo [1] use the Laplace transform to construct a method for estimating TSD from algor mortis temperature. The author gave a recent overview of different concept and techniques which includes Rainy (the author of nineteenth century), Knight, Nokes and Brown method, Henssge et al., Green et al., method and then the well-known MarshallHoare's model. The author of the nineteenth century made the first attempt to introduce the mathematical concepts. They used sequential rectal temperatures of corpses to calculate the rate of postmortem body cooling per hour and stated that it was not absolutely correct when applied to human bodies. However, Marshall's research clearly established that postmortem body cooling is not a single exponential expression, but instead, it is a curve that has a sigmoid configuration with an initial temperatur lag $[1,2]$.

The decrease of postmortem temperature is mainly determined by physical condition. Dying and death are consecutive final biological process. After death occurs, tissue metabolism does not cease immediately, but will still continue instead for some hours [3]. The function of three systems i.e. the circulatory, respiratory and nervus system are crucial to the life of the orgnism. After the irreversible cessation of respiratory or circulatory arrest of the blood flow through the whole body is diminished and the tissue will fail to receive the oxygen. And biological death will occur, which the cell of organism begin to die, is distinguished as well. The next stage is individual death, when brain and braistem death takes place [4]. With irreversible circulatory arrest, all muscles will become completely flaccid due to loss of tone [3], accompanied with the cessation of hypothalamic which failed to perform the thermoregulation function. Much body heat are generate through the skeletal muscles and these structures are the primary importance for increasingly metabolic rate and maintaining constant body temperature [5]. Postmortem interval estimation is very important task in forensic study. Development of concepts and techniques in using postmortem body cooling temperature is often used in estimation of the TSD. This assumption is not valid as can be verified from experimental result $[1,6]$. The aim to this study was to costruct a mathematical Multivariate Adaptive Regression Splines (MARS) model $[7,8]$ of PMT 
interval estimation from algor mortis (postmortem body cooling temperature) in males Rat, depend on the room at ambient temperature and condition temperature.

\section{Materials and Methods}

This study was undertaken from September to Desember 2016. Sixteen clinically healthy male rats (Rattus norvegicus), one month old and weigh 100 gram were assigned to be the animal model. The rats were randomly divided into two groups (eight/each group) and were acclimated respectively among the ambient room (temperature over $28^{\circ} \mathrm{C}$ ) and at the conditioning room (temperature over $20^{\circ} \mathrm{C}$ ) for one week before starting the experiment. The animals then were sacrificed with anesthesia using ketamin, in two days (four rats/day for each divided room between o to 22 hours after death). Then, algor mortis by rectal body temperature were recorded from each rat cadaver immediately at $\mathrm{o}$ and $2,4,6,8,10,12,14,16,18,20$ till $22 \mathrm{~h}$ postmortem respectively. The temperature measurement were taken by digital thermometer.

The collected data were analyzed by using MARS. The MARS model aims to identify the relationship between the PMT and algor mortis pattern on the ambient room or conditioning room is nonlinear regression but performed as a multilinear curve that can have splines fitting. The Result of MARS analysis PMT estimation model are: $\mathrm{Y}=\mathrm{Bo}+\mathrm{B}_{1}{ }^{\star} \mathrm{BF} 1+\mathrm{B}_{2}{ }^{\mathrm{B}} \mathrm{BF}_{2}+\ldots \ldots \ldots . . . . . . \mathrm{Bk}{ }^{\star} \mathrm{BFk}$ where $\mathrm{Y}$ : Algor mortis (postmortem body cooling temperature); Bo: temperature constanta; B1.....Bk: spline Coefficient Regression; (囚) BF1.........BFk: Basic function no 1,2.......no. k (=time interval). Criteria of the best fitting MARS estimation Model assigned by minimizing the GCV (Generalized crossvalidation criterion) [7]. If the model's performance was comprised by multilinier curve with spline, the data was analyzed by Regression Product Moment. T-test was used to determine the validity of algor mortis pattern in the time interval of death among those both difference room. Additionally, if the finding model showed that there is a significant difference ( $\mathrm{t}>\mathrm{t}$ table, with alfa 0.05 ), the next steps will be analyzing the knot of algor mortis in both of those room by comparing the regression coefficient (R2) and calculating the difference using t-test [8]. The data was calculated using Multivariate Adaptive Regression Splines (MARS) and were performed by MARS 2.0 dan XL stat 14 of statistical computer software. 


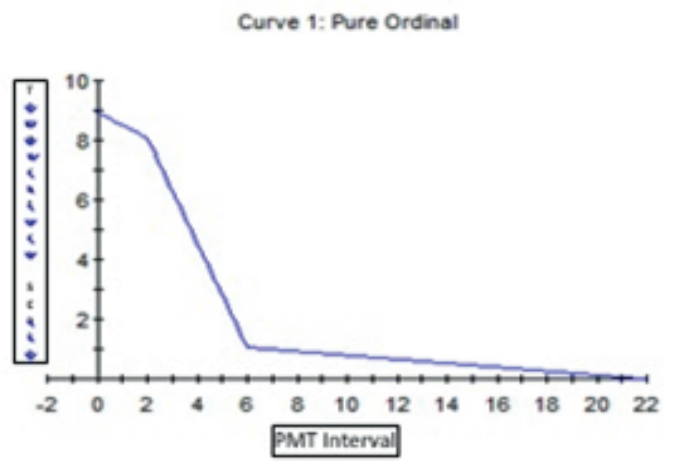

a

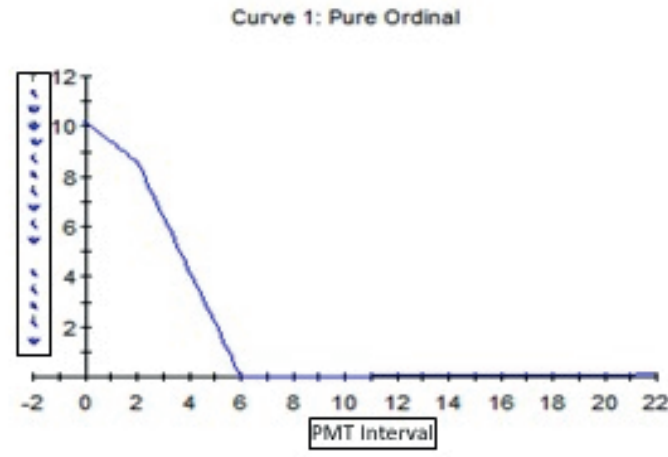

b.

Figure 1: The Relation of Posmortem Time (PMT) Interval with Algor mortis Temperature of Rat (PMT interval were 0-2 h; 2-6 h and 6-22h) a. MARS Model for Algor mortis on ambient temperature room over $28^{\circ} \mathrm{C}$ b. MARS Model for Algor mortis in $20^{\circ} \mathrm{C}$ condition room.

\section{Result and Discussion}

This result of MARS analysis, performed a model of estimation of the PMT interval from algor mortis temperature (among the ambient room and conditioning room) comprised by multilinear curve with splines as follow in Figure 1. Algor mortis temperature of rat was detected declining in the same pattern $(p<0,001)$ not only at the ambient room but also at the conditioning room.

MARS Model for Algor mortis on ambient room, was obtained with these terms and conditions i.e. $M O=0, M I=1, B F=4$, with $Y$ function $=35.321+1.253 * B F 1+0.436$ * $\mathrm{BF}_{2}-1.319$ * $\mathrm{BF}_{3} ;$ where $\mathrm{BF}_{1}=\max (0$, hour -6.000$) ; \mathrm{BF}_{2}=\max (0,6.000-$ hour $)$; $\mathrm{BF}_{3}=\max (0$, hour - 2.000); GCV = 0.273 (curve 1a) MARS Model for Algor mortis in conditioning room, was obtained with these terms and conditions: $M O=0, M I=1, B F$ $=4$, With $\mathrm{Y}$ function $=29.980+1.354$ * BF1 +0.799 * BF2 -1.347 * BF3; where $\mathrm{BF}_{1}=$ $\max (0$, hours -6.000$) ; B F_{2}=\max (0,6.000-$ hours $) ; B_{3}=\max (0$, hours- 2.000$) ; \mathrm{GCV}$ $=2.202$ (curve $1 \mathrm{~b}$ ) 


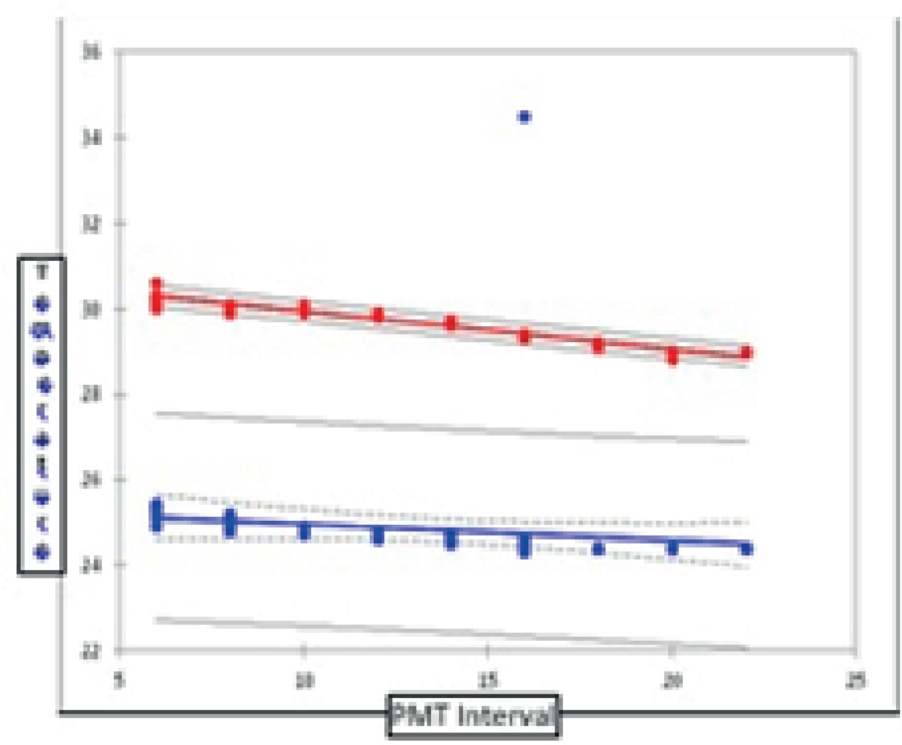

Figure 2

TABLE 1: MARS Model Postmortem Time (PMT) Interval Estimation with Algor mortis Temperature of Rat on Ambient Room and Conditioning Room.

\begin{tabular}{|c|c|c|}
\hline \multirow[t]{2}{*}{ PMT Interval } & \multicolumn{2}{|c|}{ MARS Estimation Model } \\
\hline & Ambient Room & Conditioning Room \\
\hline $0-2 h$ & $Y=37,94-0.11$ *hour* & $Y=34.78-0.09$ *hour** \\
\hline $2-6 h$ & $Y=40.88-1.87 *$ hour $* *$ & $Y=37.97-2.38 *$ hour ** \\
\hline $6-22 \mathrm{~h}$ & $Y=30.82-0.09$ *hour** & $Y=25.36-0.04$ *hour* \\
\hline \multicolumn{3}{|c|}{$\mathrm{Y}=$ algor mortis temperature } \\
\hline \multicolumn{3}{|c|}{ Body cooling decrease not significant $(p>0.05)$} \\
\hline \multicolumn{3}{|c|}{ Body cooling decrease significant $(p<0.0001)$} \\
\hline
\end{tabular}

The result of the next step analyzed that on 2-6 h PMT interval, the decline was accelerated of algor mortis at conditioning room steeper than at ambient room : $)$ 2,38 vs 1,87).

The Accelerated Decline of Algor Mortis at Ambient Room (above ß: 1,87) and at Conditioning Room (below: ß: 2,38) and in 2-6 h PMT Interval

Furthermore, considering the MARS Estimation as multilinear curve model with the splines, there are several formulation for implementing the each spline relation piecewise, which has shown on different PMT interval, defined as in table 1.

In our study, the algor mortis pattern of rat cadaver at o to $2 \mathrm{~h}$ PMT interval suggests that the rate was not significantly decreased $(p>0,005)$ at ambient room $\left(28^{\circ} \mathrm{C}\right)$, conversely at conditioning room $\left(20^{\circ} \mathrm{C}\right)$ were observed a significant decrease $(p<0,001)$.

The algormortis pattern of this study, according to the Marshall and Hoare's research, clearly established that the slow rate in the first phase and last approximately 2- $5 \mathrm{~h}$. 
The authors call is an initial phase or temperature plateau that is the lag periode during which the body temperature remain relatively constant. The temperature detected by rectal measurement as the best representation for sigmoid shape of the cooling curve later $[2,3]$.

The algormortis pattern in o to $2 \mathrm{~h}$ PMT interval, exposed the term, that dying and death are continuous final biological processes. Moreover, Madea and KernbachWighton [3] suggested that the temperature plateau was mainly determined by physical preconditions as it is due to the fact that central axial temperature cannot begin to decrease until a heat gradient was set up between the core of the body with its surface. Brown and Marshall's proposition suggested that the slow algor mortis postmortem cooling rate is due to the continuing product of the heat by the internal source of the body and removed by convection from the skin. It seems to indicate that the heat produced after the death contributes, but not totally. Irreversible respiratory or circulatory arrest is the main criterion for death, followed the early postmortem changes that predominantly body cooling [1].

The intermediate phase of our study was the investigation at 2- $6 \mathrm{~h}$ PMT interval, showed there was a rapid drop of the rate of cooling body, significantly decreased $(p<0,001)$ on both of the experimental rooms. Furthermore, the statistic analysis confirmed that the pattern of decreasing was steeper at conditioning room $20^{\circ} \mathrm{C}$ than at ambient room over $28^{\circ} \mathrm{C}$ ( $\beta: 2.38$ vs 1.87). The result pattern of this study is according to the Marshall and Hoare's sigmoid configuration curve expression [3]. Immediately after the death, the corpses cools slow at uniform rate, then followed by a straight portion of varying length and slope corresponding to the period of the quickest cooling body. It suggests that before $6 \mathrm{~h}$ after death, the tissue metabolism still has not ceased yet, but will continue for some hours by the next stage during which the cell of organism begin to die, is considered as the cessation of brain and brainstem function [4]

With irreversible respiratory and circulatory arrest, skeletal muscles will become completely flaccid due to loss of tone. In the early postmortem, ATP can be resynthesized via creatinin kinase reaction and anaerobic glycolysis [3]. Once ATP level has fallen, actin and myosin filament form a rigor-complex and initiated muscle fiber that have already become stiff. Postmortem heat production is low as anaerobic glycolysis ceases within a few hour postmortem. The transport process of heat release from internal source into the body surface firstly occured convectively and consequently was continued conductively [2]. In the immediate postmortem, dissolution of rigor mortis and livor mortis is due to protein degradation. The break down of tissues by 
autodigestive cellular enzym were occured in the early stage decomposition (autolysis). The phenomenon may be seen up to $6 \mathrm{~h}$ postmortem $[3,9]$.

Saber and Ali [10] noted that the forensic experts have long recognized that decomposition is initiated by a process called autolysis which induces detrimental alterations in the cell leading to cell death. The autolysis is the other criteria of the postmortem changes. The forensic investigators attention also has focused on biochemical changes of postmortem. Biochemical changes could be used as markers for times of death determination. The accurate determination including loss of selective membrane permeability, protein RNA and DNA degradation or loss of RNA transcription after death.

Moreover, Saber and Ali [10] using the analysis of the $m$ RNA expression of FasL, Caspase- 3 and Phosphatase and Tensin (PTEN) on chromosome 10 of gastrocnemius muscle of Rat. The results suggest that the three expression of genes depicted a gradual increase beginning $2 \mathrm{~h}$ to $4 \mathrm{~h}$ and optimum in $6 \mathrm{~h}$ and then a marked decrease at $8 \mathrm{~h}$ after the death. Indeed, as the cancer, stem cells and genetic studies that published between 1997-1999 have found that FasL is a necrosis factor that initiate cell death; Caspase- 3 is a enzyme in sharing and activate the apoptosis and PTEN plays a vital role in regulation of cell growth and apoptosis.

Thus, Saber and Ali's study (2016) of these correlation between expression level of the three genes in 2-6 $\mathrm{h}$ time since death, confirm the implicated to the pattern of decreasing postmortem cooling rate at the same time in our study.

In the terminal phase during 6-22 h PMT stages, the MARS model of our study described that the cooling of the body became gradually decreased, linear with increasingly postmortem time. The cooling decrease was significant $(p<0,001)$ at ambient room, conversely on conditioning room it was observed not significantly decrease $(p>0,001)$.

Rodrigo (2015) supports the recent researcher proposed exponential model which was found the plateau and a sigmoidal shape cooling curve. These forensic experts described that a slow falling curve of gradually decreasing gradient was occured at the final stage, similar to that ussually assosiated with cooling expressed by Newton's Law. Most of the heat removed from internal layer of the deceased body is due to convection from the skin according to a Newton's law of cooling. Earlier, in 1974 Brown and Marshall proposed, as the surface heat is lost and the outer layer of decay body start to cool, heat immediately flowing out from any subjacent layer, or from the hotter region of the body into the outer or superficial layer by conduction. The body temperature slowly dropped continuously as the core temperature approaches that of the environment and replaced the constant cooling rate and stagnant by a time [1]. 
The changes which occur if rigor phase broken before it reachs maximum development of flaccidity followed by onset of generallized muscle stiffening. The decrease of ATP in this periode is solely due the accumulation of intracelluler lactic acid and anaerobic breakdown of carbohydrat, fat and protein, there has been an extensive cellular damage related to biological death. [3, 10-12]. Zou and Byard (2011) reviewed forensic research's result stated that decomposition refers to process of tissue breakdown by self-digestion of the endogenous enzymes activity. Cessation of blood flow leads to the accumulation of waste products from damage cells, compromising cell and lysosomal membrane integrity, and reducing plasma and cytoplasmic $\mathrm{pH}$. Moreover, the rupture of lysosomal membrane leads to release of hydrolytics enzymes and then autolytic changes progress in death body. This process usually appeared between 12$18 \mathrm{~h}$ in ambient temperature.

In our study, the terminal phase of algor mortis have found that the corpses cools slow at uniform rate, linear with increasingly postmortem time and then stagnant at $24.4^{\circ} \mathrm{C}$ in $18 \mathrm{~h} \mathrm{PMT}$ interval in conditioning room and at $29^{\circ} \mathrm{C}$ in $22 \mathrm{~h} \mathrm{PMT}$ interval for cadaver in enviromentally room. This result showed that the constant and stagnant temperature algor mortis earlier replaced on cold room.

\section{Conclusions}

Postmortem Time Interval Estimation from Algormortis Temperature of Rats could be expressed by MARS Model. The pattern model of estimation comprised by multilinear curve with splines was fitted at both of the experimental rooms.

\section{References}

[1] Rodrigo M.R. (2015). Time of death estimation from temperature reading only: a Laplace transform approach. Applied Mathematics Letters 39. p 47-52. Elsevier Ltd.

[2] Cox W. A. 2009. Early postmortem changes and time death. Forensic pathologistNeoropathologist Review

[3] Madea B and G. Kernbach-Wighton, 2013. early and late post mortem changes. Encyclopedia of forensic sciences. Second ed. Elsevier Ltd.) p.217-228

[4] Listos P, M.Gryzinska and M. Kowalczyk. 2015. Analysis of cases of forensic veterinary opinions produced in a research and teaching unit. J of Forensic and Legal Medicine. Vol. 36 p. 84-89. Elsevier Ltd. 
[5] Anderson B.E. and H. Jonasson in Duke's Physiology of Domestic Animal editor: Swenson M.J and W.O. Reece) $1993.11^{\text {th }}$ ed. Comstock Publishing Assosiates Cornell Univ.Press. London.

[6] Henssege C. and B. Madea. 2007. Estimation of time since death. J.Forensic Science International 165. p.182-184. ScienceDirect. Elsevier Ireland. Ltd

[7] Sutikno. 2002. Pengunaan Regresi Splines Adaptif Berganda untuk Peramalan Indeks Enso dan Hujan Bulanan. Program Pascasarjana. Institut Pertanian Bogor. p. $28-29$

[8] Lewis, P. A.W. and J.G. Steven. 1990. Non Linear Modelling of Time Series Using Multivariate Adaptive Regression Splines (MARS). Naval Postgraduate School. Chief of Naval Research. Monterey.California. USA

[9] Ubelaker D.H. 2013. Postmortem interval. Encyclopedia of forensic sciences. Second ed. Elsevier Ltd.) p. 24-27.

[10] Saber T.M and H.A.Ali. 2016. Expression of cell death genes estimates time since death in rats. Rom J.Leg Med (24) p 164-167.

[11] Zhou C. and R.W. Byard. 2011. Factors and processes causing accelerated decomposition in human cadavers- an overview. J of Forensic and Legal Medicine. Vol. 18 p. 6-9.Elsevier Ltd.

[12] McFeeley P.J. 1997. Standard Employeed to Determined time of death. (edited by. J Kercheval). AAFS New York Meeting. 